\title{
The proapoptotic BH3-only proteins Bim and Puma are downstream of endoplasmic reticulum and mitochondrial oxidative stress in pancreatic islets in response to glucotoxicity
}

\author{
JA Wali ${ }^{1,2}$, D Rondas ${ }^{3}$, MD McKenzie ${ }^{1,4}$, Y Zhao ${ }^{1}$, L Elkerbout ${ }^{1}$, S Fynch ${ }^{1}$, EN Gurzov ${ }^{1}$, S Akira ${ }^{5}$, C Mathieu ${ }^{3}$, TWH Kay ${ }^{1,2}$, \\ L Overbergh $^{3}$, A Strasser ${ }^{4,6}$ and HE Thomas ${ }^{\star, 1,2}$
}

Apoptosis of pancreatic beta cells is a feature of type 2 diabetes and its prevention may have therapeutic benefit. High glucose concentrations induce apoptosis of islet cells, and this requires the proapoptotic $\mathrm{Bcl}-2$ homology domain 3 (BH3)-only proteins Bim and Puma. We studied the stress pathways induced by glucotoxicity in beta cells that result in apoptosis. High concentrations of glucose or ribose increased expression of the transcription factor CHOP (C/EBP homologous protein) but not endoplasmic reticulum (ER) chaperones, indicating activation of proapoptotic ER stress signaling. Inhibition of ER stress prevented ribose-induced upregulation of Chop and Puma mRNA, and partially protected islets from glucotoxicity. Loss of Bim or Puma partially protected islets from the canonical ER stressor thapsigargin. The antioxidant $\mathrm{N}$-acetyl-cysteine also partially protected islets from glucotoxicity. Islets deficient in both Bim and Puma, but not Bim or Puma alone, were significantly protected from killing induced by the mitochondrial reactive oxygen species donor rotenone. Our data demonstrate that high concentrations of glucose induce ER and oxidative stress, which causes cell death mediated by Bim and Puma. We observed significantly higher Bim and Puma mRNA in islets of human donors with type 2 diabetes. This indicates that inhibition of Bim and Puma, or their inducers, may prevent beta-cell destruction in type 2 diabetes.

Cell Death and Disease (2014) 5, e1124; doi:10.1038/cddis.2014.88; published online 13 March 2014

Subject Category: Experimental Medicine

Type 2 diabetes occurs as a result of progressive beta-cell dysfunction causing insufficient insulin secretion to compensate for insulin resistance, leading to hyperglycaemia. In addition to an insulin secretory defect, there is a contribution from a decrease in beta-cell mass as a result of apoptosis. ${ }^{1-3}$ Because the loss of beta-cell mass is a central event in type 2 diabetes, its prevention is a key therapeutic target.

High concentrations of glucose (glucotoxicity) were reported to trigger apoptosis in cultured human and mouse islets $^{4,5}$ and in animal models of type 2 diabetes. $^{6-8}$ Using gene-targeted mice lacking critical regulators of cell death, we demonstrated that a high concentration of glucose, or the reducing sugar ribose, activates the intrinsic apoptosis pathway in beta cells. In particular, the apoptosis-initiating $\mathrm{Bcl}-2$ homology domain 3 (BH3)-only proteins Bim and Puma, as well as the downstream apoptosis effector Bax, are required for glucotoxicity of beta cells in mouse islets. ${ }^{5}$

Endoplasmic reticulum (ER) stress occurs when there is accumulation of misfolded proteins in the lumen of the ER.
This activates different factors of the unfolded protein response (UPR) pathway. ${ }^{9}$ Although there is some overlap in the regulation of downstream factors, UPR pathway molecules can be broadly divided into three main arms: PERK, IRE1 $\alpha$ and ATF6. ${ }^{10}$ Markers of ER stress were increased after exposure of islets in vitro to saturated fatty acids (palmitate) and glucose, and also in vivo in islets from leptin-receptor-deficient $d b / d b$ mice, hyperglycaemic rats, ${ }^{11}$ human beta cell exposed to hyperglycaemic conditions ${ }^{12}$ and pancreatic sections of type 2 diabetic patients. ${ }^{13,14}$ ER stress has been reported to activate proapoptotic $\mathrm{BH} 3-$ only proteins, particularly Bim and Puma, in diverse cell types. Bim is upregulated in response to ER stress through the transcription factor CHOP (C/EBP homologous protein) and post-translational phosphorylation that inhibits its proteasomal degradation. ${ }^{9,15}$ Evidence from non-islet cells suggests that $\mathrm{CHOP}$ can also induce Puma gene expression. ${ }^{16-18}$

Increased production of reactive oxygen species (ROS) and subsequent oxidative stress represent another possible

\footnotetext{
${ }^{1}$ St. Vincent's Institute of Medical Research, Fitzroy, VIC, Australia; '2Department of Medicine, St. Vincent's Hospital, The University of Melbourne, Fitzroy, VIC, Australia; ${ }^{3}$ Laboratory for Clinical and Experimental Endocrinology, Leuven, Belgium; ${ }^{4}$ The Walter and Eliza Hall Institute of Medical Research, Parkville, VIC, Australia; ${ }^{5}$ Department of Host Defense, Osaka University, Osaka, Japan and ${ }^{6}$ Department of Medical Biology, The University of Melbourne, Parkville, VIC, Australia

*Corresponding author: H Thomas, Department of Immunology and Diabetes, St. Vincent's Institute of Medical Research, 41 Victoria Parade, Fitzroy, VIC 3065 , Australia. Tel: +61 39288 2480; Fax: +61 39416 2676; E-mail: hthomas@ svi.edu.au

Keywords: type 2 diabetes; apoptosis; ER stress; oxidative stress; Bim; Puma

Abbreviations: ER, endoplasmic reticulum; ROS, reactive oxygen species; $\mathrm{CHOP}, \mathrm{C} / \mathrm{EBP}$ homologous protein; $\mathrm{BH} 3$, Bcl-2 homology domain 3; UPR, unfolded protein response; TUDCA, tauroursodeoxycholic acid; PBA, 4-phenyl butyric acid; NAC, N-acetylcysteine Dedicated to Mr. Wali-Ur-Rehman (father of Jibran Abdul Wali) who passed away on February 20, 2014. Received 05.11.13; revised 03.2.14; accepted 05.2.14; Edited by M Federici
} 
mechanism by which high concentrations of glucose could kill beta cells. Pertinently, beta cells have only low expression of antioxidant enzymes rendering them susceptible to damage by ROS. ${ }^{19,20}$ Exposure of human and rat islets to high concentrations of glucose or ribose resulted in increased production of intracellular ROS, ${ }^{21,22}$ and overexpression of the antioxidant enzyme glutathione peroxidase protected rat islets from ribose toxicity. ${ }^{22}$ There is also some evidence that the intrinsic apoptosis pathway may be activated in beta cells by oxidative stress. Oxidative stress upregulated $\mathrm{Hrk} / \mathrm{DP} 5$ gene expression ${ }^{23}$ and caused an almost $50 \%$ decrease in the expression of the caspase- 9 inhibitor CARD8. ${ }^{24}$

Because of the proposed role of ER and oxidative stress in beta-cell loss in type 2 diabetes and our previous discovery that glucotoxicity activates the intrinsic apoptotic pathway in beta cells, we sought to determine whether ER and/or oxidative stress constitute the upstream activators of apoptosis in this setting. We found that activation of the proapoptotic BH3-only proteins Bim and Puma in response to glucotoxicity is dependent on the induction of both ER stress and mitochondrial oxidative stress. Furthermore, consistent with our findings in mouse islets, we observed significantly more proapoptotic $\mathrm{BH} 3$-only gene expression in islets of human subjects with type 2 diabetes.

\section{Results}

ER stress induces apoptosis in islets that is dependent on Bim and Puma. To determine whether Bim and Puma act downstream of ER stress in beta cells, wild-type islets were incubated for 4-5 days with low-dose $(5 \mu \mathrm{M})$ thapsigargin and cell death was examined. Thapsigargin induced a marked increase in cells with fragmented DNA (a hallmark of apoptosis) in wild-type islets, and this was significantly reduced in Bim- or Puma-deficient islets (Figures $1 \mathrm{a}$ and $\mathrm{b}$ ). Similar results were obtained when tunicamycin $(10 \mu \mathrm{g} / \mathrm{ml})$ was used to induce ER stress (Figure 1c). This shows that the proapoptotic BH3-only proteins Bim and Puma are required for ER stress-induced islet cell death. These data are consistent with other studies using different inducers of ER stress in FACS-purified beta cells. ${ }^{25,26}$

Glucotoxicity induces ER stress that activates UPR signaling to initiate apoptosis. We next determined whether ER stress-mediated UPR can be induced by glucose. For in vitro treatment, we used the reducing sugar ribose $(50 \mathrm{mM})$, which can enter the cell through glucose transporters and be metabolized through the pentose phosphate pathway and glycolysis. Like other reducing sugars, including glucose or fructose, ribose induces islet cell death through glycation and formation of ROS, ${ }^{22}$ but over a shorter time frame. The levels of mRNAs for UPR pathway components were examined in wild-type islets by qPCR. Expression of Chop but not ATF4 increased in islets cultured with ribose, and this increase was statistically significant after 2 days (Figure 2a). Moreover, IRE $1 \alpha$-mediated splicing of XBP1 gradually increased with ribose treatment and was significantly increased after 3 days, whereas unspliced XBP1 mRNA expression did not change (Figure 2a). There was a marginal decrease in expression of the ATF6-regulated chaperones BiP and Pdia4 after the first day of ribose incubation, but expression of the cochaperone P58 was not affected by the exposure of islets to ribose (Figure 2a). Treatment of cultured islets with $33.3 \mathrm{mM}$ glucose for 7 days produced the same results (data not shown).

Consistent with the findings from the qPCR analysis, treatment of islets with ribose caused a marked increase in CHOP protein after 2 days, whereas BiP levels remained constant (Figure 2b).

CHOP is required for glucotoxicity-mediated ER stress in islets. Because CHOP was increased in islets in response to ribose and glucose exposure, the role of $\mathrm{CHOP}$ in mediating ER stress-induced islet cell apoptosis was further examined. Islets cultured with ribose plus the ER stress inhibitor tauroursodeoxycholic acid (TUDCA) had significantly lower expression of CHOP when compared with islets cultured with ribose alone (Figure 3a).

Interestingly, the glutathione precursor $\mathrm{N}$-acetylcysteine (NAC) also reduced the impact of ribose on CHOP expression, suggesting that, in addition to ER stress, CHOP expression may also be enhanced by increased ROS levels as a consequence of protein misfolding in the ER lumen ${ }^{27,28}$ (Figure 3a). Upon treatment with $50 \mathrm{mM}$ ribose for 4 days or 33.3 mM glucose for 6 days, islets lacking $\mathrm{CHOP}$ had reduced numbers of apoptotic cells compared with wild-type islets (Figures $3 \mathrm{~b}$ and $\mathrm{c}$ ). These data indicate that $\mathrm{CHOP}$ is required for ER stress-induced apoptosis of islet cells in response to glucotoxicity.
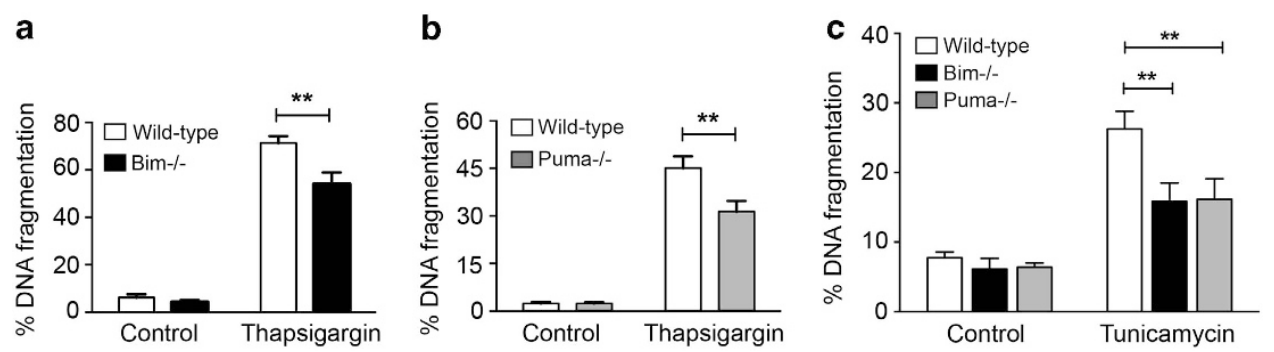

Figure 1 ER stress activates intrinsic apoptosis in islet cells. (a-c) Islets from wild-type $\mathrm{C} 57 \mathrm{BL} / 6, \mathrm{Bim}^{-/-}$or Puma ${ }^{-/-}$mice were cultured in a control medium or in a medium containing $5 \mu \mathrm{M}$ thapsigargin for 5 days (a) or 4 days (b), or $10 \mu \mathrm{g} / \mathrm{ml}$ tunicamycin for 4 days (c). The frequency of cells undergoing DNA fragmentation was measured by flow cytometry. Results represent mean \pm s.e.m. of $n=4$ independent experiments. ${ }^{* *} P<0.01$ when comparing wild-type to Bim $^{-1-}$ or wild-type to Puma ${ }^{-/-}$islets cultured with thapsigargin or tunicamycin (two-way ANOVA) 

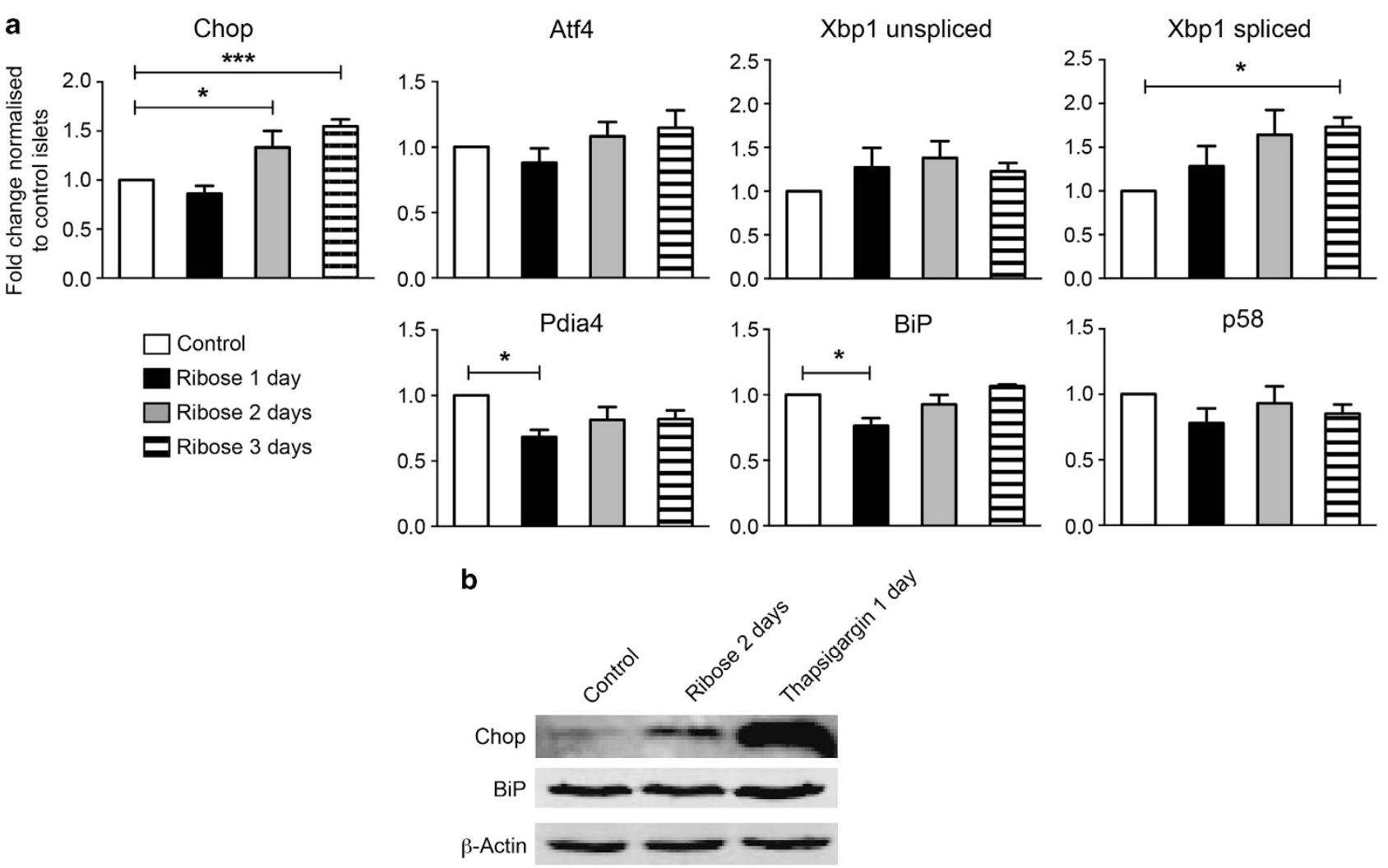

Figure 2 Glucose toxicity activates the PERK and IRE $1 \alpha$ arms of the UPR pathway. (a) Quantitative RT-PCR of wild-type C57BL/6 islets cultured for 1 to 3 days either in a control medium or in a medium containing $50 \mathrm{mM}$ ribose. Relative mRNA expression levels for Chop, Att4, Bip, Pdia4, P58 and XBP1-unspliced/spliced were calculated by normalizing to the signal for $\beta$-Actin mRNA in each sample and comparison with islets cultured in a control medium. Results represent mean \pm s.e.m. of $n=3-6$ independent experiments. ${ }^{*} P<0.05,{ }^{* * *} P<0.001$ when comparing islets cultured in ribose with those cultured in a control medium (one-way ANOVA). (b) Eight hundred wild-type C57BL/6 islets were cultured in a control medium or in a medium containing $50 \mathrm{mM}$ ribose. Positive control islets were cultured in $5 \mu \mathrm{m}$ thapsigargin. Western blotting was performed with antibodies to $\mathrm{CHOP}(31 \mathrm{kDa}), \mathrm{BiP}(78 \mathrm{kDa})$ and $\beta$-Actin $(45 \mathrm{kDa})$ (loading control). Results are representative of three independent experiments

\section{CHOP regulates Puma expression in islets with ER stress}

Attenuation of ER stress reduces Puma expression: To examine whether ribose-induced $\mathrm{CHOP}$ activation results in increased expression of downstream proapoptotic targets, gene expression of Bim and Puma was studied in ribosetreated islets. The expression of Puma increased by almost threefold in islets treated with ribose and this increase could be prevented by addition of the ER stress inhibitor TUDCA (Figure 4a). This demonstrates that CHOP and Puma are both regulated by TUDCA-sensitive processes. Thapsigargin also induced a marked increase in Puma mRNA expression. Although NAC efficiently diminished the ribose-induced increase in $\mathrm{CHOP}$ levels, it did not impair Puma induction (Figure 4a), suggesting that ribose can induce Puma expression independent of oxidative stress. The presence or absence of TUDCA or NAC had no impact on Bim mRNA in islets cultured for 3 days with ribose (Figure $4 \mathrm{~b}$ ). This reveals that Bim mRNA levels do not change with alterations in CHOP mRNA abundance.

Chop regulates Puma expression in islets: To examine whether CHOP induces apoptosis in islets by increasing transcription of downstream proapoptotic targets, ${ }^{9}$ we studied the mRNA expression of Bim, Puma and Bax in wild-type and $\mathrm{CHOP}$-deficient islets that had been treated with $50 \mathrm{mM}$ ribose for 3 days (Figure 4c). The expression of Puma was significantly reduced in ribose treated Chop ${ }^{-1-}$ islets when compared with similarly treated wild-type islets (Figure 4c). This indicates that $\mathrm{CHOP}$ regulates Puma expression in islets that are subject to ER stress. In contrast, loss of CHOP did not affect Bim or Bax mRNA expression in ribose-treated islets (Figure $4 \mathrm{c}$ ). Compared with wild-type islets, islets from $\mathrm{Chop}^{-/-}$mice also had reduced BiP mRNA expression, perhaps indicating that CHOP deficiency changes the balance between the induction of proapoptotic and prosurvival factors in the UPR pathway, resulting in reduced baseline ER stress in islets (Figure $4 \mathrm{c}$ ). Treatment with ribose did not increase BiP expression in wild-type and CHOP-deficient islets when they were compared with control (untreated) islets of similar genotype (Figure 4c).

Puma regulation by Chop is not mediated by Akt-FoxO3a signaling: It has been suggested that the transcription factor FOXO3a regulates the expression of Bim and Puma in neurons and haematopoietic cells. ${ }^{29-32}$ Phosphorylated (activated) Akt was shown to cause inhibitory phosphorylation of $\mathrm{FOXO3a}$, thereby preventing its nuclear translocation 


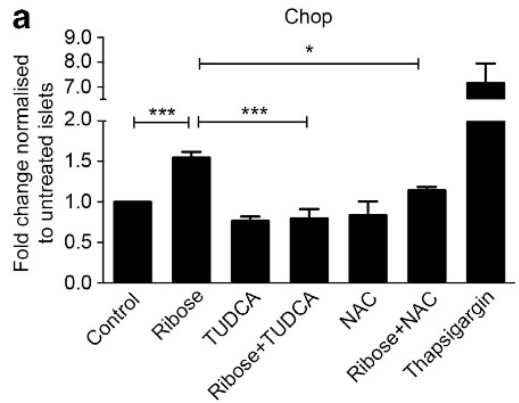

b

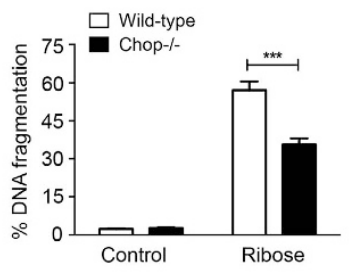

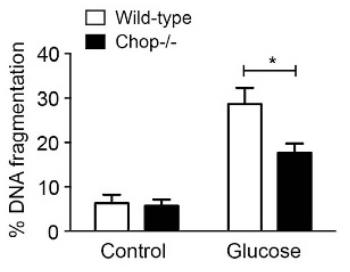

Figure 3 Downregulation or loss of Chop inhibits ER stress-induced apoptosis. (a) Quantitative RT-PCR of wild-type C57BL/6 islets cultured for 3 days in a control medium or in a medium containing $50 \mathrm{mM}$ ribose, $0.5 \mathrm{mM}$ TUDCA or $1.0 \mathrm{mM} \mathrm{NAC}$ for 3 days. Relative mRNA expression levels for Chop were calculated by normalizing to the signal for $\beta$-Actin mRNA in each sample and comparison with islets cultured in a control medium. Treatment with thapsigargin ( $5 \mu \mathrm{M}$ for 1 day) was used as a positive control. Results represent mean \pm s.e.m. of $n=5$ independent experiments. ${ }^{*} P<0.05,{ }^{* \star *} P<0.001$ (one-way ANOVA). (b and $\left.\mathbf{c}\right)$ The frequency of cells undergoing DNA fragmentation was measured by flow cytometry in islets from wild-type and $\mathrm{Chop}^{-1-}$ mice that had been cultured in a control medium containing $5.5 \mathrm{mM}$ glucose or a medium containing $50 \mathrm{mM}$ ribose for 4 days (b) or $33.3 \mathrm{mM}$ glucose for 6 days (c). Results represent mean \pm s.e.m. of $n=3$ independent experiments. ${ }^{*} P<0.05$, ${ }^{* * *} P<0.001$ when comparing islets from $\mathrm{Chop}^{-1-}$ mice with those from wild-type mice (two-way ANOVA)

a

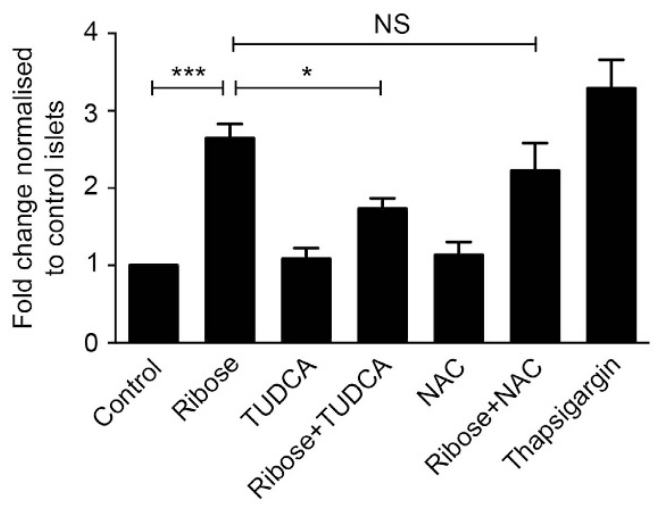

C

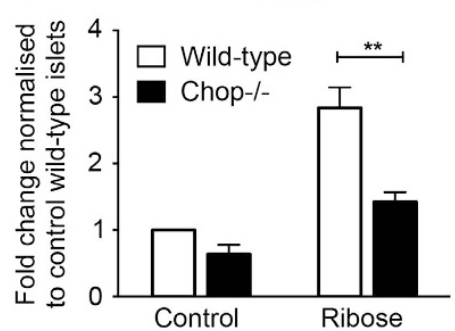

Puma

Bim

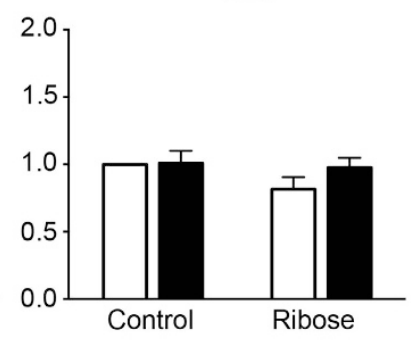

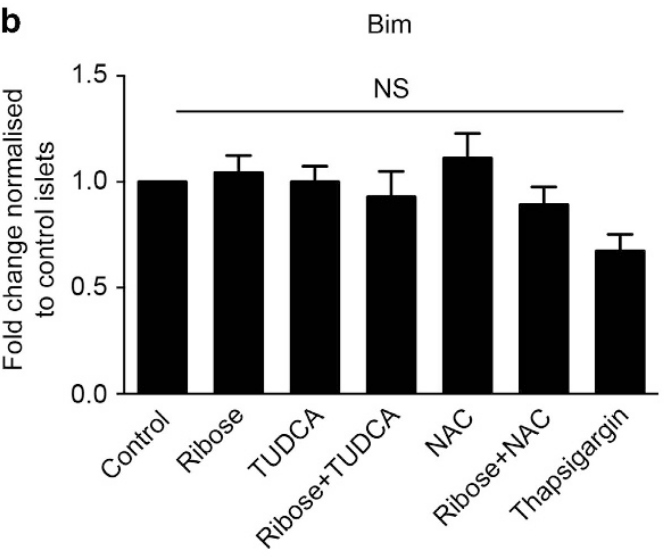

Bax
BiP

d
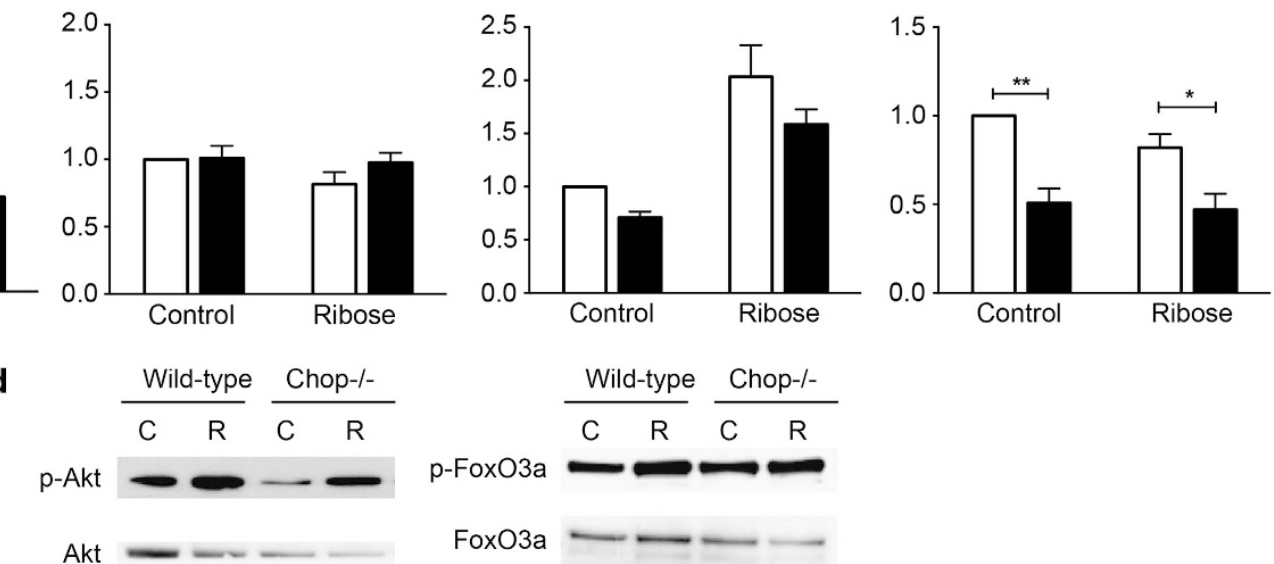

Figure 4 CHOP controls Puma expression in islet cells undergoing ER stress. (a and $\mathbf{b}$ ) Quantitative RT-PCR of wild-type C57BL/6 islets cultured for 3 days in a control medium or in a medium containing $50 \mathrm{mM}$ ribose, $0.5 \mathrm{mM}$ TUDCA or $1.0 \mathrm{mM} \mathrm{NAC}$. Relative mRNA expression levels for Puma (a) and Bim (b) were calculated by normalizing to the signal for $\beta$-Actin mRNA in each sample and comparison with islets cultured in a control medium. Treatment with thapsigargin ( $5 \mu \mathrm{M}$ for 1 day) was used as a positive control. Results represent mean \pm s.e.m. of $n=3-5$ independent experiments. NS $=$ not significant. ${ }^{*} P<0.05,{ }^{* * \star} P<0.001$ (one-way ANOVA). (c) Quantitative RT-PCR of islets from wild-type C57BL/6 and Chop $^{-1-}$ mice that had been cultured for 3 days either in a control medium or in a medium containing $50 \mathrm{mM}$ ribose. Relative mRNA expression levels for Bim, Puma, Bax and Bip were calculated by normalizing to the signal for $\beta$-Actin mRNA in each sample and comparison with wild-type islets cultured in a control medium. Results represent mean \pm s.e.m. of $n=5$ independent experiments. ${ }^{*} P<0.05$, ${ }^{* *} P<0.01$ when comparing islets cultured in ribose with those cultured in a control medium (two-way ANOVA). (d) Western blot analysis with antibodies to phosphorylated Akt (p-Akt, $60 \mathrm{kDa}$ ) and total Akt (loading control), and phophorylated FoxO3a (p-FoxO3a, $95 \mathrm{kDa}$ ) and total FoxO3a (loading control). A total of 400-700 islets were cultured for 2 days in a control medium or in a medium containing $50 \mathrm{mM}$ ribose. Results are representative of four independent experiments 
and induction of target genes, such as Bim or Puma. ER stress was reported to inhibit phosphorylation of Akt in a CHOP-dependent manner. ${ }^{30}$ The levels of phosphorylated (activated) FOXO3a and pAkt were similar in ribose-treated $\mathrm{Chop}^{-/-}$islets compared with similarly treated wild-type islets (Figure 4d). These data suggest that CHOP-dependent FOXO3a activation may not be required for regulating Puma expression in islets, indicating that ER stress must activate Puma through other processes in these cells.

ER stress-induced Bim and Puma activation mediates glucotoxicity in islets. To determine whether glucotoxicityinduced proapoptotic ER stress signaling results in Bim- and Puma-dependent cell death, we used the chemical inhibitors of ER stress TUDCA and 4-phenyl butyric acid (PBA). Addition of PBA or TUDCA partially protected islets from wild-type mice against ribose-induced cell death, as demonstrated by a reduction in cells exhibiting DNA fragmentation (Figures $5 \mathrm{a}$ and $\mathrm{b}$ ). In islets lacking Bim or Puma, riboseinduced cell killing was significantly lower when compared with wild-type islets, as described previously ${ }^{5}$. The cell death in Bim- or Puma-deficient islets was further reduced when PBA or TUDCA was added to the culture medium, with the frequency of cells undergoing DNA fragmentation being not significantly different from islets cultured with PBA or TUDCA alone (Figures $5 a$ and $b$ ). Similar results were obtained when islets were cultured with $33.3 \mathrm{mM}$ glucose together with TUDCA (Figure 5c). These results suggest that inhibition of ER stress protects islets from glucotoxicity and deficiency of Bim or Puma reduces residual ER stress-mediated cell death in TUDCA-treated islets.

Mitochondrial oxidative stress induces Bim- and Pumadependent apoptosis in islets. Previous reports showed that exposure to high concentrations of glucose or ribose lead to increased ROS production in rat and human islets. ${ }^{21,22}$ We investigated the involvement of oxidative stress in glucose-induced islet cell killing. First, we cultured islets in hydrogen peroxide $\left(\mathrm{H}_{2} \mathrm{O}_{2}\right)$ at low concentrations $(30 \mu \mathrm{M})$ that have been shown to induce apoptosis but not necrosis in non-islet cells. ${ }^{33,34}$ Absence of Bim or Puma, or both Bim and Puma, did not protect islets from $\mathrm{H}_{2} \mathrm{O}_{2}$-induced
DNA fragmentation (Figure 6a). Addition of the pancaspase inhibitor qVD.oph also failed to inhibit $\mathrm{H}_{2} \mathrm{O}_{2}$ toxicity (Figure 6a). This suggests that in contrast to certain other cell types, inhibition of apoptosis does not protect islet cells from cell death caused by cytosolic oxidative stress.

Next, islets were treated with the mitochondrial electron transport chain complex-I inhibitor rotenone (100 nM), which induces oxidative stress selectively in the mitochondria. ${ }^{35}$ Combined loss of Bim and Puma significantly inhibited rotenone-induced islet cell death (Figure $6 b$ ). Protection from rotenone toxicity was only partial, possibly because rotenone is known to also induce some necrosis. ${ }^{35}$ Overall, these data suggest that mitochondrial oxidative stress induces apoptosis in islet cells that utilizes both Bim and Puma proteins.

Oxidative stress-induced Bim and Puma activation mediates glucotoxicity in islets. We used dihydrodicholorofluorescein $\left(\mathrm{H}_{2} \mathrm{DCF}\right)$ to measure intracellular ROS. ROS production increased after ribose treatment for 3 days, and this was inhibited by the mitochondrial ROS scavenger NAC $(1 \mathrm{mM})^{36}$ (Figure $6 \mathrm{c}$ ). When we cultured islets with ribose or glucose in the presence of NAC, DNA fragmentation of wildtype islets was reduced by almost $50 \%$ (Figures $6 \mathrm{~d}$ and e). This suggests that oxidative stress is required for glucoseinduced islet cell killing. In contrast to the findings with the ER stress inhibitors TUDCA and PBA (see above), loss of Bim or Puma did not cooperate with NAC to provide enhanced protection against ribose- or glucose-induced islet cell killing (Figures $6 \mathrm{c}$ and $\mathrm{d}$ ). These results suggest that inhibition of oxidative stress protects islets from glucotoxicity, but deletion of either Bim or Puma on their own does not reduce the residual oxidative stress-mediated cell killing in NAC-treated islets. This is consistent with our observation that combined loss of Bim and Puma are required to block islet cell killing elicited by mitochondrial ROS toxicity.

Expression of proapoptotic genes is higher in islets from human type 2 diabetic donors. Hyperglycaemia is an important feature of type 2 diabetes. The presence of oxidative stress ${ }^{3,37}$ and increased expression of UPR pathway factors such as $\mathrm{CHOP}^{14}$ has been observed in islets from type 2 diabetic individuals. We investigated if
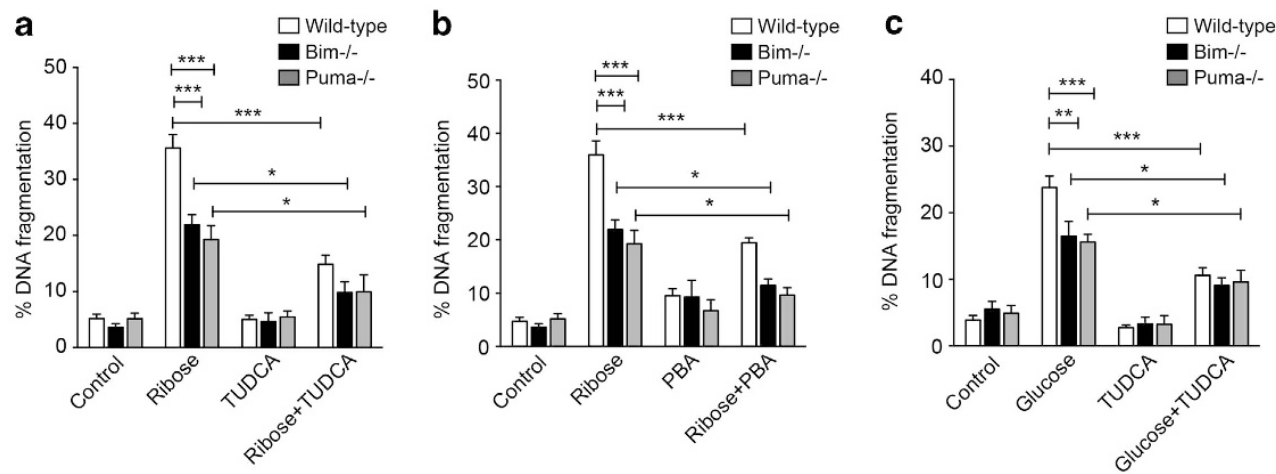

Figure 5 Attenuation of ER stress protects islet cells from glucotoxicity. The frequency of cells undergoing DNA fragmentation was measured by flow cytometry after incubation of wild-type C57BL/6, Puma ${ }^{-1-}$ or Bim ${ }^{-1-}$ islets for 4 days with $50 \mathrm{mM}$ ribose, $0.5 \mathrm{mM}$ TUDCA (a) or $2.5 \mathrm{mM} \mathrm{PBA} \mathrm{(b)} \mathrm{or} 33.3 \mathrm{mM}$ glucose and $0.5 \mathrm{mM}$ TUDCA for 6-7 days (c). Control islets were incubated in a medium containing $5.5 \mathrm{mM}$ glucose. Results represent mean \pm s.e.m. of $n \geq 6$ independent experiments. ${ }^{*} P<0.05$, ${ }^{* *} P<0.01,{ }^{* * *} P<0.001$ (two-way ANOVA) 


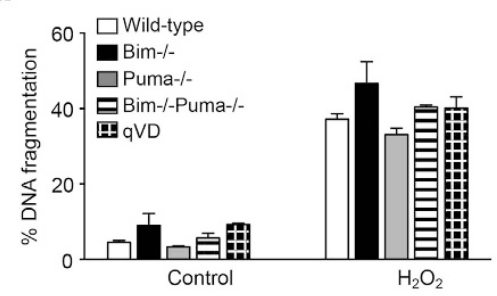

b

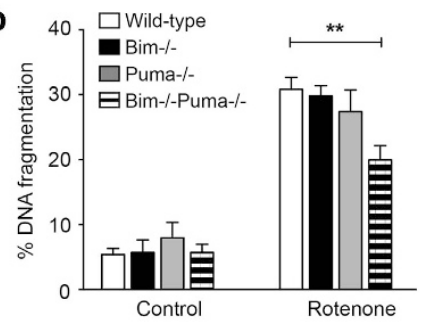

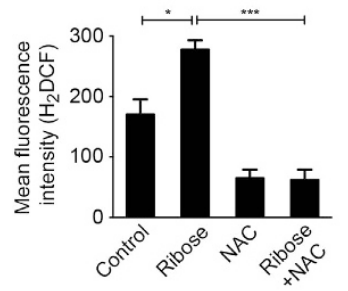

d

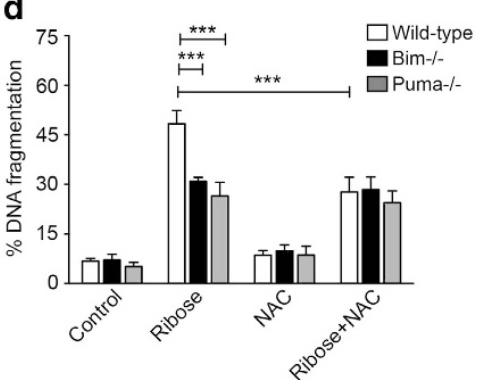

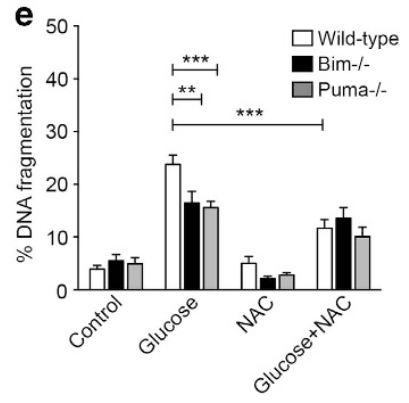

Figure 6 Inhibition of oxidative stress protects islet cells from glucotoxicity. (a and $\mathbf{b})$ The frequency of cells undergoing DNA fragmentation was measured by flow cytometry after incubation of wild-type C57BL/6, Bim ${ }^{-1-}$ Puma $^{-1-}$, Bim ${ }^{-1-}$ or Puma ${ }^{-1-}$ islets with $30 \mu \mathrm{M} \mathrm{H}_{2} \mathrm{O}_{2}$ and $50 \mu \mathrm{M}$ pancaspase inhibitor qVD.oph for 2 days (a), or $100 \mathrm{nM}$ Rotenone for 2 days (b). Control islets were incubated for 2 days in a medium containing $5.5 \mathrm{mM}$ glucose. Results represent mean \pm s.e.m. of $n \geq 4$ independent experiments. ${ }^{*} P<0.01{ }^{* *} P<0.001$ (two-way ANOVA). (c) Mean fluorescence intensity of $\mathrm{H}_{2} \mathrm{DCF}$ staining measured by flow cytometry after incubation of MIN6 cells with $50 \mathrm{mM}$ ribose with or without $1.0 \mathrm{mM}$ NAC for 3 days. Results are mean \pm s.e.m. of $n=3-4$ independent experiments. ${ }^{*} P<0.05$, ${ }^{* \star \star} P<0.001$ (one-way ANOVA). (d and e) The frequency of cells undergoing DNA fragmentation was measured by flow cytometry after incubation of wild-type C57BL/6, Puma ${ }^{-1-}$ or Bim ${ }^{-1-}$ islets with $50 \mathrm{mM}^{\text {ribose }}$ with or without $1.0 \mathrm{mM} \mathrm{NAC}$ for 4 days (d), or $33.3 \mathrm{mM}$ glucose with our without $1.0 \mathrm{mM} \mathrm{NAC}$ for 6-7 days (e). Control islets were incubated in a medium containing $5.5 \mathrm{mM}$ glucose. Results represent mean \pm s.e.m. of $n \geq 5$ independent experiments. ${ }^{* *} P<0.01,{ }^{* * *} P<0.001$ (two-way ANOVA)

proapoptotic molecules are also upregulated in human type 2 diabetes. Islets were isolated from non-diabetic and agematched type 2 diabetic donors (Supplementary Table S1) and gene expression of Bim, Puma, Bax and Bid were studied by qRT-PCR. Bim mRNA was almost threefold higher, whereas Puma and Bax were nearly twofold higher in islets of type 2 diabetic donors when compared with nondiabetic donors (Figure 7). Federici et al..$^{38}$ observed an increase in expression of Bid, a $\mathrm{BH} 3$-only molecule involved in the extrinsic apoptosis pathway in beta cells after culture in high glucose concentrations. ${ }^{38}$ Although we did not observe a significant increase in Bid expression, it remains possible that its expression is increased in islets from a subset of type 2 diabetic individuals. Overall our data suggest that type 2 diabetes-associated oxidative and ER stress is accompanied by activation of intrinsic apoptotic signaling in islets.

\section{Discussion}

This study shows that exposure to high concentrations of glucose kills islet cells by inducing proapoptotic ER and oxidative stress signaling and downstream activation of the intrinsic apoptotic pathway. The ER stress pathway-associated transcription factor $\mathrm{CHOP}$ and the proapoptotic $\mathrm{BH} 3-$ only proteins Bim and Puma are essential for this process. This is in contrast to physiological glucose concentration, which does not result in islet cell apoptosis.

Substantial inhibition of cell death in wild-type islets with TUDCA and PBA indicates that ER stress is a major contributor to beta-cell glucotoxicity. Deficiency of either Bim or Puma alone partially reduced this cell death, indicating that ER stress can activate both of these proteins to initiate apoptosis, thereby suggesting overlapping, additive roles for these two molecules in glucotoxicity in islet cells. This is consistent with the previous finding that glucose- or riboseinduced islet cell death is reduced to background levels after combined deletion of Bim and Puma. ${ }^{5}$ Overlapping actions of Bim and Puma have previously been detected with several apoptotic stimuli in a range of cell types (e.g. treatment of lymphoid cells with glucocorticoids ${ }^{39}$ ). The dominant role of Bim and Puma in the initiation of apoptosis can in part be explained by the fact that (unlike many other BH3-only proteins) they can bind and inhibit all prosurvival Bcl-2 family members. ${ }^{40}$

Upregulation of the transcription factor $\mathrm{CHOP}$ represents an important mechanism through which ER stress initiates apoptosis. CHOP has been suggested to induce cell death through various mechanisms that include depleting cellular glutathione and sensitizing the cell to oxidative stress, upregulation of proapoptotic genes ${ }^{15}$ and downregulation of the prosurvival molecule Bcl-2. ${ }^{9,41}$ ER stress, through activation of $\mathrm{CHOP}$, has been shown to activate the proapoptotic molecules Bim and Puma in several cell types and tissues. ${ }^{15,16,42}$ Conversely, Puma was found to be a critical mediator of ER stress-induced apoptosis in mouse embryonic fibroblasts ${ }^{43}$ and mouse motor neurons. ${ }^{44}$ In mouse islets, Puma expression followed a similar pattern to the induction of $\mathrm{CHOP}$. This suggests that CHOP is critical for the ER stressinduced increase in Puma expression in beta cells, similar to hepatocytes ${ }^{16}$ and neuronal cells. ${ }^{42} \mathrm{CHOP}$ deficiency did not 


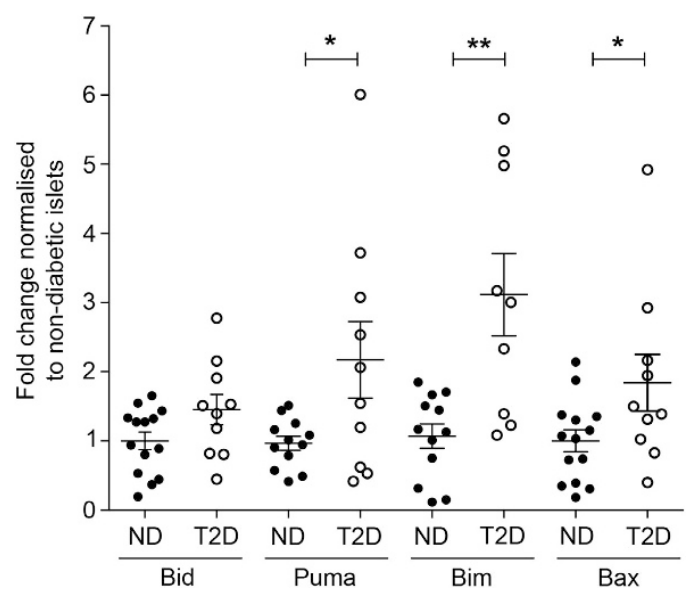

Figure 7 Proapoptotic intrinsic pathway genes are upregulated in human islets in type 2 diabetes. Quantitative RT-PCR of human islets isolated from non-diabetic (ND; $n=12-14$ ) and age-matched type 2 diabetic (T2D; $n=9-10$ ) donors. Relative mRNA expression levels for Bim, Puma, Bax and Bid were calculated by normalizing to the signal for $18 S$ and Actin mRNA in each sample. Results represent mean \pm s.e.m. ${ }^{*} P<0.05,{ }^{*} P<0.01$ when comparing gene expression in islets of type 2 diabetic donors with those non-diabetic donors (unpaired $t$-test)

affect Puma expression in control (untreated) islets, suggesting that Puma mRNA levels may not be influenced by ER stress pathway factors under basal conditions.

Bim transcript abundance remained unchanged after exposure to ribose with or without addition of TUDCA, consistent with our previous report. ${ }^{5}$ This raises the possibility that $\mathrm{CHOP}$ may be required for maintaining a high basal expression of Bim through a mechanism that does not affect Bim in conditions of increased ER stress. The finding that stronger ER stress inducers, such as thapsigargin, also failed to increase Bim expression supports this hypothesis. However, loss of CHOP did not cause a reduction in the basal levels of Bim expression, suggesting that ER stress may affect Bim expression post-translationally. ${ }^{15,45,46}$

The significant reduction in ribose- and glucose-induced cell death in wild-type islets afforded by treatment with NAC indicated that, in addition to ER stress, oxidative stress is also an important mediator of glucose and ribose toxicity. Mitochondrial oxidative stress, but not cytosolic oxidative stress, was more important in activating intrinsic apoptosis in islets. This is not surprising as increased metabolism caused by high glucose concentrations will result in upregulated electron transport chain activity and ROS generation in the mitochondria. ${ }^{47}$ Consistent with our findings, a previous study showed that upregulation of Puma protein expression was seen in mitochondrial fractions of neuronal cells treated with drugs that induce oxidative stress. ${ }^{18}$ The increase in Bim protein levels was also limited to the mitochondrial fraction and was much more sensitive to mitochondrial ROS than cytosolic ROS. ${ }^{18}$ In contrast to ER stress, we observed that oxidative stress-induced apoptosis of islet cells required both Bim and Puma. It is possible that in contrast to the relatively mild toxicity induced by ER stress, ROS toxicity is more severe, possibly because of lower antioxidant expression in islet cells. ${ }^{19,20}$ Therefore, combined loss of both Bim and
Puma is required to abrogate the intrinsic apoptosis triggered by this insult.

Increased expression of Bim Puma and Bax in the islets of human type 2 diabetic subjects suggest that similar to mouse islets, oxidative and ER stress activate intrinsic apoptosis in human islets. While exposure of mouse islets to high glucose or ribose concentrations did not cause an increase in Bim expression, the increased expression observed in human islets indicates that prolonged and combined exposure to high glucose, lipids and amyloid (conditions that are normally seen in human type 2 diabetes) may be required to cause an increase in Bim gene expression. Although we did not directly demonstrate expression of these molecules in purified beta cells, there is sufficient evidence in the literature for expression and function of proapoptotic Bcl-2 family members in rodent beta cells and dispersed human islets to suggest that increased expression in beta cells at least in part contributes to the differences observed in islets from type 2 diabetic individuals. ${ }^{25,45,48-50}$

ER and oxidative stress are the major pathways by which beta cells are destroyed in type 2 diabetes. Activation of the intrinsic apoptosis pathway downstream of both of these stress pathways in islets, and their upregulation in islets from type 2 diabetic donors, suggests a central role for the BH3only proteins Bim and Puma in the loss of beta-cell mass in type 2 diabetes. Thus, these stress and apoptosis pathways need to be inhibited to prevent beta-cell loss in type 2 diabetes. The challenge will now be to design inhibitors of these pathways that are suitable for in vivo use in patients.

\section{Materials and Methods}

Mice. Mice deficient for Bim (generated using 129SV-derived ES cells and backcrossed for $>10$ generations onto the C57BL/6 background) and Puma (generated using C57BL/6-derived ES cells) have been described previously. ${ }^{5,51,52}$ Mice deficient in Chop (generated using 129/Ola ES cells), backcrossed for 10 generations onto the C57BL/6 background, have been described previously ${ }^{53}$. All animal experiments were approved by the Institutional Animal Ethics Committees.

Reagents. D-Glucose (used at $33.3 \mathrm{mM})$ and D-ribose $(50 \mathrm{mM})$ were purchased from Invitrogen (Invitrogen Corporation, Grand Island, NY, USA) and SigmaAldrich (St. Louis, MO, USA), respectively. Similar concentrations of L-glucose or L-ribose were used as hyperosmolarity controls (data not shown). ${ }^{5}$ Thapsigargin (used at $5 \mu \mathrm{M}$ ) was purchased from Calbiochem (Darmstadt, Germany). Anisomycin (Sigma-Aldrich) was used at $1 \mu \mathrm{g} / \mathrm{ml}$ concentration. TUDCA (SigmaAldrich) was used at $0.5 \mathrm{mM}$, PBA (Sigma-Aldrich) at $2.5 \mathrm{mM}$, NAC (Sigma-Aldrich) at $1.0 \mathrm{mM}, \mathrm{H}_{2} \mathrm{O}_{2}$ (Sigma-Aldrich) at $30 \mu \mathrm{M}$ and Rotenone (Sigma-Aldrich) at $100 \mathrm{nM}$. The concentrations of TUDCA, PBA, NAC, $\mathrm{H}_{2} \mathrm{O}_{2}$ and Rotenone were titrated to determine optimal culture conditions. Control conditions contained the same concentration of diluent (DMSO for rotenone, tunicamycin and Q-VD-OPh, ethanol for thapsigargin or $\mathrm{NaOH}$ for $\mathrm{PBA}$, other reagents were made up in complete CMRL medium) in the complete medium.

Islet isolation, culture and DNA fragmentation assay. Islets of Langerhans were isolated as described previously. ${ }^{54}$ Islets were washed, handpicked and cultured overnight at $37^{\circ} \mathrm{C}$ in $5 \% \mathrm{CO}_{2}$ in $\mathrm{CMRL}$ medium- 1066 (Invitrogen) supplemented with $100 \mathrm{U} / \mathrm{ml}$ penicillin, $100 \mu \mathrm{g} / \mathrm{ml}$ streptomycin, $2 \mathrm{mmol} / /$ glutamine and 10\% FCS (JRH Biosciences, Lenexa, KS, USA) (referred to below as complete CMRL). Following incubation with different reagents, islets were trypsinized and DNA fragmentation was analysed by staining with PI and flow cytometric analysis as described previously. ${ }^{5}$ MIN6 cells were a kind gift from Dr. Jun-ichi Miyazaki. ${ }^{55} \mathrm{H}_{2} \mathrm{DCF}$ staining was performed on MIN6 cells according to the manufacturer's instructions (Cell Biolabs, San Diego, CA, USA). 
Human pancreata were obtained, with informed consent from next-of-kin, from heart-beating, brain-dead donors by the Australian Islet Transplant Consortium. The project was approved by the human ethics committees of the hospitals involved and the Australian Red Cross. Human islets were isolated as described previously. ${ }^{48}$ Islets were immediately snap frozen in liquid nitrogen and stored at $-80^{\circ} \mathrm{C}$ before they were used to isolate RNA. Donor details are provided in Supplementary Table S1.

Real-time quantitative RT-PCR analysis. RNA was prepared using the NucleoSpin RNA XS (Macherey Nagel, Düren, Germany). First-strand cDNA was prepared from 200 to $300 \mathrm{ng}$ RNA using the High Capacity CDNA Reverse Transcription kit (Applied Biosystems, Foster City, CA, USA). c-DNA was diluted $(1: 100)$ and real-time PCR was performed using the Rotor-Gene RG-3000 machine (Corbett Research; Qiagen, Hilden, Germany) and the TaqMan PCR Master Mix (AmpliTaq Gold with GeneAmp kit; Applied Biosystems) in $20 \mu \mathrm{l}$ reaction volumes. Data analyses were performed with the $\triangle \Delta C T$ method using $\beta$-Actin as an internal control. qRT-PCR analyses for Att4, Chop, Bip, Pdia4, P58, Bim, Puma and Bax were performed using the commercially available TaqMan gene expression assay kits for mouse genes (Applied Biosystems). qRT-PCR for Xbp1 (unspliced) and Xbp1s (spliced) was performed with Custom TaqMan gene expression assay primers and probes (Applied Biosystems) using the sequences published previously. ${ }^{56}$ For human islets, qRT-PCRs were performed using the commercially available TaqMan gene expression assay kits (Applied Biosystems) using Actin and $18 \mathrm{~S}$ as housekeeping genes.

Western blotting. Islets (number of islets described in figures) were incubated for the indicated time points with the reagents described above, then washed with PBS and finally lysed in $15 \mu \mathrm{l}$ of lysis buffer $(20 \mathrm{mmol} / \mathrm{I}$ Tris- $\mathrm{HCl}(\mathrm{pH}$ 7.4), $135 \mathrm{mmol} / / \mathrm{NaCl}, 1.5 \mathrm{mmol} / / \mathrm{MgCl}_{2}, 1 \mathrm{mmol} / / \mathrm{EGTA}, 1 \%$ Triton X-100, $1 \times$ protease inhibitor cocktail and $1 \times$ phosphatase inhibitor cocktails 1 and 2). Western blotting was performed using standard procedures with antibodies to actin (Santa Cruz Biotechnology, Santa Cruz, CA, USA), CHOP (Enzo Life Sciences, Farmingdale, NY, USA), BiP, phosphorylated and total Akt and FoXO3a (all from Cell Signaling Technology, Danvers, MA, USA). Detection of CHOP, FoxO3a and Akt was with horseradish peroxidase-conjugated secondary antibody (SouthernBiotech, Birmingham, AL, USA) and detection with ECL + Western blotting detection system (GE Healthcare, Little Chalfont, UK). For all other antibodies, Alexa Fluor 680 goat antibodies to mouse IgG (Invitrogen) or IR Dye $800 \mathrm{CW}$ donkey antibodies to rabbit IgG (LI-COR, Lincoln, NE, USA) were used as secondary antibodies, and blots were examined using the ODYSSEY infrared imager (LI-COR).

Statistical analysis. Statistical analysis was performed using GraphPad Prism Software (San Diego, CA, USA). All data shown as bar graphs are mean \pm s.e.m. Data were analysed by one- or two-way ANOVA with Bonferroni's or Dunnett's post-test for comparison of multiple columns (as appropriate). Human qPCR data was analysed by upaired $t$-test.

\section{Conflict of Interest}

The authors declare no conflict of interest.

Acknowledgements. We thank Drs. P Bouillet and D Gray (Walter and Eliza Hall Institute) for Bim/Puma-deficient mice, Dr J Miyazaki (Osaka University) for MIN6 cells, Drs. J Allison and E Carrington (St. Vincent's Institute) for intellectual input, Dr. T Loudovaris and Ms L Mariana (Australian Islet Transplant Consortium, St. Vincent's Institute) for human islets and S Thorburn, D Novembre-Cycon, R Branch and A Gomes for genotyping and animal husbandry. This study was supported by a National Health and Medical Research Council of Australia (NHMRC) and Juvenile Diabetes Research Foundation (JDRF) joint special program grant in type 1 diabetes (APP466658), an NHMRC project grant (APP1032610), a fellowship from the NHMRC (HET), a University of Melbourne Viola Edith Reid Bequest Scholarship (JAW) and postdoctoral fellowships from the JDRF (YZ, EG). This study was supported in part by the Victorian Government's Operational Infrastructure Support Program.

1. Butler AE, Janson J, Bonner-Weir S, Ritzel R, Rizza RA, Butler PC. Beta-cell deficit and increased beta-cell apoptosis in humans with type 2 diabetes. Diabetes 2003; 52 : 102-110.
2. Clark A, Wells CA, Buley ID, Cruickshank JK, Vanhegan RI, Matthews DR et al. Islet amyloid, increased A-cells, reduced B-cells and exocrine fibrosis: quantitative changes in the pancreas in type 2 diabetes. Diabetes Res 1988; 9: 151-159.

3. Sakuraba H, Mizukami H, Yagihashi N, Wada R, Hanyu C, Yagihashi S. Reduced beta-cell mass and expression of oxidative stress-related DNA damage in the islet of Japanese Type II diabetic patients. Diabetologia 2002; 45: 85-96.

4. Maedler K, Schulthess FT, Bielman C, Berney T, Bonny C, Prentki M et al. Glucose and leptin induce apoptosis in human beta-cells and impair glucose-stimulated insulin secretion through activation of c-Jun N-terminal kinases. FASEB J 2008; 22: 1905-1913.

5. McKenzie MD, Jamieson E, Jansen ES, Scott CL, Huang DC, Bouillet $P$ et al. Glucose induces pancreatic islet cell apoptosis that requires the $\mathrm{BH}$-only proteins Bim and Puma and multi-BH domain protein Bax. Diabetes 2010; 59: 644-652.

6. Donath MY, Gross DJ, Cerasi E, Kaiser N. Hyperglycemia-induced beta-cell apoptosis in pancreatic islets of Psammomys obesus during development of diabetes. Diabetes 1999; 48: $738-744$.

7. Pick A, Clark J, Kubstrup C, Levisetti M, Pugh W, Bonner-Weir S et al. Role of apoptosis in failure of beta-cell mass compensation for insulin resistance and beta-cell defects in the male Zucker diabetic fatty rat. Diabetes 1998; 47: 358-364.

8. Song B, Scheuner D, Ron D, Pennathur S, Kaufman RJ. Chop deletion reduces oxidative stress, improves beta cell function, and promotes cell survival in multiple mouse models of diabetes. J Clin Invest 2008; 118: 3378-3389.

9. Eizirik DL, Cardozo AK, Cnop M. The role for endoplasmic reticulum stress in diabetes mellitus. Endocr Rev 2008; 29: 42-61.

10. Hotamisligil GS. Endoplasmic reticulum stress and the inflammatory basis of metabolic disease. Cell 2010; 140: 900-917.

11. Tang C, Koulajian K, Schuiki I, Zhang L, Desai T, Ivovic A et al. Glucose-induced beta cell dysfunction in vivo in rats: link between oxidative stress and endoplasmic reticulum stress. Diabetologia 2012; 55: 1366-1379.

12. Kennedy J, Katsuta H, Jung MH, Marselli L, Goldfine AB, Balis UJ et al. Protective unfolded protein response in human pancreatic beta cells transplanted into mice. PLoS One 2010; 5: e11211.

13. Cunha DA, Hekerman P, Ladriere L, Bazarra-Castro A, Ortis F, Wakeham MC et al. Initiation and execution of lipotoxic ER stress in pancreatic beta-cells. J Cell Sci 2008; 121 : 2308-2318.

14. Laybutt DR, Preston AM, Akerfeldt MC, Kench JG, Busch AK, Biankin AV et al. Endoplasmic reticulum stress contributes to beta cell apoptosis in type 2 diabetes. Diabetologia 2007; 50: 752-763.

15. Puthalakath H, O'Reilly LA, Gunn P, Lee L, Kelly PN, Huntington ND et al. ER stress triggers apoptosis by activating BH3-only protein Bim. Cell 2007; 129: 1337-1349.

16. Cazanave SC, Elmi NA, Akazawa Y, Bronk SF, Mott JL, Gores GJ. CHOP and AP-1 cooperatively mediate PUMA expression during lipoapoptosis. Am J Physiol Gastrointest Liver Physiol 2010; 299: G236-G243.

17. Giam M, Huang DC, Bouillet $\mathrm{P}$. BH3-only proteins and their roles in programmed cell death. Oncogene 2008; 27(Suppl 1): S128-S136.

18. Steckley D, Karajgikar M, Dale LB, Fuerth B, Swan P, Drummond-Main C et al. Puma is a dominant regulator of oxidative stress induced Bax activation and neuronal apoptosis. J Neurosci 2007; 27: 12989-12999.

19. Jonas JC, Bensellam M, Duprez J, Elouil H, Guiot Y, Pascal SM. Glucose regulation of islet stress responses and beta-cell failure in type 2 diabetes. Diabetes Obes Metab 2009; 11(Suppl 4): 65-81.

20. Lenzen S, Drinkgern J, Tiedge M. Low antioxidant enzyme gene expression in pancreatic islets compared with various other mouse tissues. Free Radic Biol Med 1996; 20: 463-466.

21. Moore PC, Ugas MA, Hagman DK, Parazzoli SD, Poitout V. Evidence against the involvement of oxidative stress in fatty acid inhibition of insulin secretion. Diabetes 2004; 53: $2610-2616$

22. Tanaka Y, Tran PO, Harmon J, Robertson RP. A role for glutathione peroxidase in protecting pancreatic beta cells against oxidative stress in a model of glucose toxicity. Proc Natl Acad Sci USA 2002; 99: 12363-12368.

23. Cai Y, Martens GA, Hinke SA, Heimberg H, Pipeleers D, Van de Casteele M. Increased oxygen radical formation and mitochondrial dysfunction mediate beta cell apoptosis under conditions of AMP-activated protein kinase stimulation. Free Radic Biol Med 2007; 42: 64-78.

24. Wang M, Crager M, Pugazhenthi S. Modulation of apoptosis pathways by oxidative stress and autophagy in beta cells. Exp Diabetes Res 2012; 2012: 647914.

25. Gurzov EN, Germano CM, Cunha DA, Ortis F, Vanderwinden JM, Marchetti P et al. P53 up-regulated modulator of apoptosis (PUMA) activation contributes to pancreatic beta-cell apoptosis induced by proinflammatory cytokines and endoplasmic reticulum stress. J Biol Chem 2010; 285: 19910-19920.

26. Gurzov EN, Ortis F, Bakiri L, Wagner EF, Eizirik DL. JunB inhibits ER stress and apoptosis in pancreatic beta cells. PLoS One 2008; 3: e3030.

27. Ariyama Y, Tanaka Y, Shimizu H, Shimomura K, Okada S, Saito T et al. The role of CHOP messenger RNA expression in the link between oxidative stress and apoptosis. Metabolism 2008; 57: 1625-1635.

28. Malhotra JD, Miao H, Zhang K, Wolfson A, Pennathur S, Pipe SW et al. Antioxidants reduce endoplasmic reticulum stress and improve protein secretion. Proc Natl Acad Sci USA 2008; 105: 18525-18530.

29. Dijkers PF, Birkenkamp KU, Lam EW, Thomas NS, Lammers JW, Koenderman L et al. FKHR-L1 can act as a critical effector of cell death induced by cytokine withdrawal: protein 
kinase B-enhanced cell survival through maintenance of mitochondrial integrity. J Cell Biol 2002; 156: 531-542.

30. Ghosh AP, Klocke BJ, Ballestas ME, Roth KA. CHOP potentially co-operates with FOXO3a in neuronal cells to regulate PUMA and BIM expression in response to ER stress. PLOS One 2012; 7: e39586.

31. Gilley J, Coffer PJ, Ham J. FOXO transcription factors directly activate bim gene expression and promote apoptosis in sympathetic neurons. Jf Cell Biol 2003; 162: 613-622.

32. You H, Pellegrini M, Tsuchihara K, Yamamoto K, Hacker G, Erlacher M et al. FOXO3adependent regulation of Puma in response to cytokine/growth factor withdrawal. J Exp Med 2006; 203: 1657-1663

33. Saito Y, Nishio K, Ogawa Y, Kimata J, Kinumi T, Yoshida $Y$ et al. Turning point in apoptosis/necrosis induced by hydrogen peroxide. Free Radic Res 2006; 40: 619-630.

34. Barbouti A, Doulias PT, Nousis L, Tenopoulou M, Galaris D. DNA damage and apoptosis in hydrogen peroxide-exposed Jurkat cells: bolus addition versus continuous generation of $\mathrm{H}(2) \mathrm{O}(2)$. Free Radic Biol Med 2002; 33: 691-702.

35. Li N, Ragheb K, Lawler G, Sturgis J, Rajwa B, Melendez JA et al. Mitochondrial complex I inhibitor rotenone induces apoptosis through enhancing mitochondrial reactive oxygen species production. J Biol Chem 2003; 278: 8516-8525

36. Ye YC, Wang HJ, Yu L, Tashiro S, Onodera S, Ikejima T. RIP1-mediated mitochondrial dysfunction and ROS production contributed to tumor necrosis factor alpha-induced L929 cell necroptosis and autophagy. Int Immunopharmacol 2012; 14: 674-682.

37. Del Guerra S, D'Aleo V, Gualtierotti G, Pandolfi R, Boggi U, Vistoli $F$ et al. Evidence for a role of frataxin in pancreatic islets isolated from multi-organ donors with and without type 2 diabetes mellitus. Horm Metab Res 2012; 44: 471-475.

38. Federici M, Hribal M, Perego L, Ranalli M, Caradonna Z, Perego C et al. High glucose causes apoptosis in cultured human pancreatic islets of Langerhans: a potential role fo regulation of specific $\mathrm{Bcl}$ family genes toward an apoptotic cell death program. Diabetes 2001; 50: 1290-1301.

39. Erlacher M, Labi V, Manzl C, Bock G, Tzankov A, Hacker G et al. Puma cooperates with $\mathrm{Bim}$, the rate-limiting BH3-only protein in cell death during lymphocyte development, in apoptosis induction. J Exp Med 2006; 203: 2939-2951.

40. Willis SN, Fletcher Jl, Kaufmann T, van Delft MF, Chen L, Czabotar PE et al. Apoptosis initiated when BH3 ligands engage multiple Bcl-2 homologs, not Bax or Bak. Science 2007 315: 856-859.

41. Fonseca SG, Gromada J, Urano F. Endoplasmic reticulum stress and pancreatic beta-cell death. Trends Endocrinol Metab 2011; 22: 266-274.

42. Galehdar Z, Swan P, Fuerth B, Callaghan SM, Park DS, Cregan SP. Neuronal apoptosis induced by endoplasmic reticulum stress is regulated by ATF4-CHOP-mediated induction of the Bcl-2 homology 3-only member PUMA. J Neurosci 2010; 30: 16938-16948.

43. Li J, Lee B, Lee AS. Endoplasmic reticulum stress-induced apoptosis: multiple pathways and activation of p53-up-regulated modulator of apoptosis (PUMA) and NOXA by p53. Biol Chem 2006; 281: 7260-7270.

44. Kieran D, Woods I, Villunger A, Strasser A, Prehn JH. Deletion of the BH3-only protein puma protects motoneurons from ER stress-induced apoptosis and delays motoneuron loss in ALS mice. Proc Natl Acad Sci USA 2007; 104: 20606-20611.
45. Santin I, Moore F, Colli ML, Gurzov EN, Marselli L, Marchetti P et al. PTPN2, a candidate gene for type 1 diabetes, modulates pancreatic beta-cell apoptosis via regulation of the BH3-only protein Bim. Diabetes 2011; 60: 3279-3288.

46. Nogueira TC, Paula FM, Villate O, Colli ML, Moura RF, Cunha DA et al. GLIS3, a susceptibility gene for type 1 and type 2 diabetes, modulates pancreatic beta cell apoptosis via regulation of a splice variant of the BH3-only protein Bim. PLoS Genet 2013; 9 : e1003532.

47. Robertson RP. Chronic oxidative stress as a central mechanism for glucose toxicity in pancreatic islet beta cells in diabetes. J Biol Chem 2004; 279: 42351-42354

48. Campbell PD, Weinberg A, Chee J, Mariana L, Ayala R, Hawthorne WJ et al. Expression of pro- and antiapoptotic molecules of the Bcl-2 family in human islets postisolation. Cell Transplant 2012; 21: 49-60.

49. Colli ML, Nogueira TC, Allagnat F, Cunha DA, Gurzov EN, Cardozo AK et al. Exposure to the viral by-product dsRNA or Coxsackievirus B5 triggers pancreatic beta cell apoptosis via a Bim/Mcl-1 imbalance. PLoS Pathogen 2011; 7: e1002267.

50. Cunha DA, Igoillo-Esteve M, Gurzov EN, Germano CM, Naamane N, Marhfour I et al. Death protein 5 and p53-upregulated modulator of apoptosis mediate the endoplasmic reticulum stress-mitochondrial dialog triggering lipotoxic rodent and human beta-cell apoptosis. Diabetes 2012; 61: 2763-2775.

51. Bouillet P, Metcalf D, Huang DC, Tarlinton DM, Kay TW, Kontgen F et al. Proapoptotic Bcl2 relative Bim required for certain apoptotic responses, leukocyte homeostasis, and to preclude autoimmunity. Science 1999; 286: 1735-1738.

52. Villunger A, Michalak EM, Coultas L, Mullauer F, Bock G, Ausserlechner MJ et al. p53- and drug-induced apoptotic responses mediated by $\mathrm{BH} 3-$ only proteins puma and noxa. Science 2003; 302: 1036-1038.

53. Oyadomari S, Koizumi A, Takeda K, Gotoh T, Akira S, Araki E et al. Targeted disruption of the Chop gene delays endoplasmic reticulum stress-mediated diabetes. J Clin Invest 2002; 109: 525-532.

54. McKenzie MD, Dudek NL, Mariana L, Chong MM, Trapani JA, Kay TW et al. Perforin and Fas induced by IFNgamma and TNFalpha mediate beta cell death by OT-I CTL. Int Immunol 2006; 18: 837-846.

55. Miyazaki J, Araki K, Yamato E, Ikegami H, Asano T, Shibasaki Y et al. Establishment of a pancreatic beta cell line that retains glucose-inducible insulin secretion: special reference to expression of glucose transporter isoforms. Endocrinology 1990; 127: 126-132.

56. Hayashi A, Kasahara T, Iwamoto K, Ishiwata M, Kametani M, Kakiuchi C et al. The role of brain-derived neurotrophic factor (BDNF)-induced XBP1 splicing during brain development. J Biol Chem 2007; 282: 34525-34534. published by Nature Publishing Group. This work is licensed under a Creative Commons Attribution-NonCommercialNoDerivs 3.0 Unported License. To view a copy of this license, visit http://creativecommons.org/licenses/by-nc-nd/3.0/

Supplementary Information accompanies this paper on Cell Death and Disease website (http://www.nature.com/cddis) 